\title{
HUBUNGAN DUKUNGAN SUAMI TERHADAP TINGKAT KECEMASAN IBU PRIMIGRAVIDA TRIMESTER III DALAM MENGHADAPI PERSALINAN DI RUMAH SAKIT TK II UDAYANA DENPASAR
}

\author{
The Relationship of Husband Support To The Anxiety Level of Primigravida \\ Trimester III Mothers in Facing Labor in Tk II Udayana Hospital, Denpasar \\ Arianty Duany Sinaga ${ }^{1}$, Luh Putu Widiastini ${ }^{2}$ \\ ${ }^{1}$ Jurusan Kebidanan, Stikes Bina Usada Bali, Indonesia \\ ${ }^{2}$ Jurusan Kebidanan, Stikes Bina Usada Bali, Indonesia \\ Korespondensi: Luh Putu Widiastini dan enick.dilaga@gmail.com
}

\begin{abstract}
ABSTRAK
Latar Belakang: Kehamilan suatu keadaan fisiologis, tetapi juga dapat menjadi suatu kekhawatiran bagi mereka. Selama kehamilan tidak sedikit ibu yang mengalami rasa takut dan cemas, karena kehamilan periode kritis maturitas yang dapat menimbulkan stress. Dukungan suami yang diberikan kepada wanita hamil dapat menumbuhkan perasaan tenang, aman, dan nyaman sehingga dapat mempengaruhi kecemasan ibu hamil. Tujuan Penelitian: Penelitian ini bertujuan untuk mengetahui hubungan dukungan suami terhadap tingkat kecemasan ibu hamil primigravida trimester III dalam menghadapi persalinan. Metedologi: Metode penelitian ini merupakan penelitian deskriktif korelasi dengan menggunakan populasi sebanyak 28 orang ibu hamil primigravida trimester III, dengan tehnik sampel yang digunakan adalah total sampling yaitu populasi sebagai sampel. Data diuji dengan menggunakan metode uji cross sectional, dengan menggunakan kuisioner dalam pengumpulan data. Analisa data merupakan lanjutan dari pengolahan data. Analisa yang digunakan adalah analisa univariant dan bivariant, untuk menentukan hubungan variable yang terkait dengan uji chi - square dengan tingkat kepercayaan 95\% dengan nilai alpa 0,05 , bila pValue $\leq$ 0,05 maka uji statistic bermakna, jika pValue $>0,05$ maka hasil tidak bermakna. Hasil: Hasil penelitian ini menunjukkan terdapat hubungan yang bermakna antara dukungan suami dengan tingkat kecemasan ibu primigravida trimester III dengan nilai Value = 0,463 dengan nilai significannya 0,013. Kesimpulan: Sehingga dapat disimpulkan ada hubungan antara kecemasan dan dukungan suami dalam menghadapi persalinan. Diharapkan perawat bisa menerapkan penelitian lebih lanjut tentang hubungan tingkat kecemasan primigravida trimester III dalam menghadapi persalinan.
\end{abstract}

Kata Kunci: Primigravida trimester III; dukungan suami; tingkat kecemasan.

\section{ABSTRACT}

Background: Pregnancy is a physiological state, but it can also be a concern for them. During pregnancy not a few mothers experience fear and anxiety, because pregnancy is a critical period of maturity which can cause stress. Husband's support given to pregnant women can foster feelings of calm, security, and comfort so that it can affect the anxiety of pregnant women. Objectives: This study aims to determine the relationship of husband's support to the anxiety level of primigravida pregnant women in the third trimester in facing childbirth. Methodology: This research method is a descriptive correlation research using a population of 28 pregnant women primigravida 
Arianty Duany Sinaga \& Luh Putu Widiastini: Hubungan Dukungan Suami Terhadap Tingkat Kecemasan Ibu Primigravida Trimester III dalam Menghadapi Persalinan di Rumah Sakit Tk II Udayana Denpasar

third trimester, with the sample technique used is total sampling, namely the population as a sample. The data were tested using the cross sectional test method, using a questionnaire in data collection. Data analysis is a continuation of data processing. The analysis used is univariant and bivariant analysis, to determine the relationship between variables related to the chi-square test with a 95\% confidence level with an alpha value of 0.05 , if pValue 0.05 then the statistical test is significant, if pValue $>$ 0.05 then results are meaningless. Result: The results of this study indicate that there is a significant relationship between husband's support and the anxiety level of third trimester primigravida mothers with Value $=0.463$ with a significant value of 0.013 . Conclusion: It is hoped that nurses can apply further research on the relationship between levels of anxiety in third trimester primigravida in dealing with childbirth.

Keyword: Primigravida; trimester III; husband's support; anxiety level.

\section{PENDAHULUAN}

Angka Kematian Ibu (AKI) merupakan salah satu indicator dalam Sustainable Development Goals (SDGs ) yang akan dicapai tahun 2030 (WHO, 2010). Target yang dicanangkan di Indonesia yakni 102 per 100.000 kelahiran hidup pada tahun 2015 (Depkes RI,2011).

Menurut Kusmiayati (2009), kehamilan adalah pertumbuhan dan perkembangan janin intra uteri mulai dari konsepsi dan berakhir sampai permulaan persalinan. Dalam proses kehamilan terjadi perubahan anatomi fisiologis, selain perubahan tersebut ibu hamil mengalami ketidaknyamanan dalam kehamilan.

Selama kehamilan tidak sedikit ibu mengalami rasa takut dan cemas karena periode kehamilan merupakan periode kritis maturitas yang dapat menimbulkan stress.Sekitar 15 juta perempuan mengalami kecacatan jangka panjang akibat dari komplikasi - komplikasi selama kehamilan

Menurut WHO menyebutkan bahwa kecemasan yang dialami bukti ilmiah yang dikeluarkan oleh WHO Mental Health Gap Action Programme ( $\mathrm{mh}$ $G A P$ ) pada tahun 2013, $16-25 \%$. Di dunia terungkap data bahwa dalam persalinan sekitar 12.230.142. juta jiwa dari $30 \%$ diantaranya karena kecemasan sebab hamil pertama (Medicastore, 2013). Menurut penelitian di Indonesia tahun 2012 hampir $78 \%$ ibu yang mengalami kecemasan pada akhir kehamilan, sedangkan $20 \%$ dialami oleh ibu yang multigravida, terdapat sekitar $45 \%$ ibu dari tiap 100 ibu bersalin yang mengalami kecemasan pada persalinan (Infokita, 2013). Salah satu hal yang dapat dilakukan untuk mengurangi kecemasan pada ibu hamil adalah dukungan suami.

Dukungan suami dan peran serta suami selama kehamilan meningkatkan kesiapan ibu hamil dalam menghadapi persalinan, suami dapat member perhatian dan membina hubungan baik dengan istri sehingga setiap masalah yang dialami dapat teratasi.

Berdasarkan studi pendahuluan yang telah dilakukan di POLI BKIA pada 3 bulan terakhir dari tanggal 9 Juli sampai 30 September 2016 kunjungan ibu hamil terdapat130 orang, diantaranya $52,0 \%$ orang ibu primigravida trimester III, sedangkan 28 orang ibu hamil trimester III $(53,8 \%)$ mengalami kecemasan saat menghadapi persalinan, dan 24 ibu hamil trimester III (46,2 \%) yang sudah siap menghadapi persalinan 
Arianty Duany Sinaga \& Luh Putu Widiastini: Hubungan Dukungan Suami Terhadap Tingkat Kecemasan Ibu Primigravida Trimester III dalam Menghadapi Persalinan di Rumah Sakit Tk II Udayana Denpasar

\section{TUJUAN PENELITIAN}

Berdasarkan data diatas penulis ingin lebih jauh lagi mengenai hubungan dukungan suami terhadap tingkat kecemasan ibu primigravida di Rumah Sakit Tk II Udayana

\section{METODE PENELITIAN}

Metode penelitian ini merupakan penelitian deskriptif korelasi, yang menggunakan rancangan penelitian metode cross sectional. Rancangan ini bertujuan untuk melihat hubungan dukungan suami terhadap tingkat kecemasan ibu primigravida trimester III dalam menghadapi persalinan. Populasi pada penelitian ini adalah seluruh ibu hamil primigravida trimester III sebanyak 28 orang, Sampel penelitian ini diambil dari jumlah populasi sebanyak 28 orang dengan menggunkan tehnik sampling yaitu menggunakan populasi sebagai sampel.

Uji coba instrument dilakukan dengan uji validitas dan uji reabilitas tiap pertanyaan, Uji coba ini dilakukan sebelum penelitian dengan menyebarkan instrument berupa kuisioner, yang di uji cobakan kepada responden yang bukan merupakan anggota sampel penelitian.

Prosedur pengumpulan data yang dilakukan peneliti dalam mengumpulkan data adalah prosedur administratif dan prosedur teknisi

\section{HASIL PENELITIAN}

\section{a. Analisa Univariant}

Pada penelitian ini populasinya adalah Ibu hamil primigravida trimester III yang akan melahirkan di Rumah Sakit Tingkat II Udayana . Pada penelitian ini sampelnya adalah ibu hamil yang didapat adalah sebanyak 28 orang yang menggunakan total sampling. Variabel dalam penelitian ini adalah tingkat kecemasan dan hubungan dukungan suami pada ibu hamil primigravida trimester III. Karakteristik subyek penelitian dapat dilihat pada usia ibu.

Tabel 1

Responden Berdasarkan Usia Pada

Ibu Primigravida Trimester III di Poli BKIA R.S.AD Udayana Tk II Udayana

\begin{tabular}{clcc}
\hline No & Umur & Fekuensi & $\begin{array}{c}\text { Persentase } \\
(\%)\end{array}$ \\
\hline 1 & $<20$ Tahun & 5 & 17,9 \\
\hline 2 & $20-35$ Tahun & 16 & 57,1 \\
\hline 3 & $>35$ Tahun & 7 & 25,0 \\
\hline & Total & 28 & 100,0 \\
\hline
\end{tabular}

Berdasarkan tabel di atas, menunjukkan bahwa karakteristik Ibu Hamil trimester III berdasarkan umur, sebagian besar yaitu sebanyak 16 responden (57.1\%) berumur 20-35 tahun.

\section{Tabel 2}

\section{Responden Berdasarkan Pendidikan Pada Ibu Primigravida Trimester III di Pol BKIA R.S.A D Udayana Tk II Udayana}

\begin{tabular}{clcc}
\hline No & Pendidikan & Fekuensi & $\begin{array}{c}\text { Persentase } \\
(\%)\end{array}$ \\
\hline 1 & SMP & 5 & 17,9 \\
\hline 2 & SMA/SMK & 16 & 57,1 \\
\hline 3 & $\begin{array}{l}\text { Perguruan } \\
\text { Tinggi }\end{array}$ & 7 & 25,0 \\
\hline & Total & 28 & 100,0 \\
\hline
\end{tabular}

Berdasarkan tabel di atas, menunjukkan bahwa karakteristik Ibu hamil berdasarkan pendidikan, sebagian besar yaitu sebanyak 16 responden $(57,1 \%)$ berpendidikan SMA/SMK. Tingkat pendidikan seorang wanita baik juga akan mempengaruhi bagaimana ia menyikapi proses persalinan. 
Arianty Duany Sinaga \& Luh Putu Widiastini: Hubungan Dukungan Suami Terhadap Tingkat Kecemasan Ibu Primigravida Trimester III dalam Menghadapi Persalinan di Rumah Sakit Tk II Udayana

Tabel 3

Responden Berdasarkan Pekerjaan

Pada Ibu Primigravida Trimester III di Poli BKIA R.S.A D Tk II Udayana

\begin{tabular}{clcc}
\hline No & Pekerjaan & Fekuensi & $\begin{array}{c}\text { Persentase } \\
(\%)\end{array}$ \\
\hline 1 & $\begin{array}{l}\text { Ibu Rumah } \\
\text { Tangga }\end{array}$ & 15 & 53,6 \\
\hline 2 & Swasta & 6 & 21,4 \\
\hline 3 & Guru & 4 & 14,3 \\
\hline 4 & Wiraswasta & 3 & 10,7 \\
\hline & Total & 28 & 100,0 \\
\hline
\end{tabular}

Berdasarkan tabel di atas, menunjukkan bahwa pekerjaan Ibu Hamil tersebut, sebagian besar yaitu Ibu Rumah Tangga sebanyak 15 responden $(53,6 \%)$.

Hasil penelitian tentang pelaksanaan penelitian Hubungan Dukungan Suami terhadapTingkat Kecemasan Ibu Hamil Trimester III di Rumah Sakit Tingkat II Udayana seperti tabel berikut;

\section{Tabel 5}

Distribusi Frekuensi Dukungan Suami Pada Ibu Primigravida Trimester III Di Poli BKIA R.S.A D Tk II Udayana

\begin{tabular}{clcc}
\hline No & \multicolumn{1}{c}{$\begin{array}{c}\text { Dukungan } \\
\text { Suami }\end{array}$} & $\begin{array}{c}\text { Fekuen } \\
\text { si }\end{array}$ & $\begin{array}{c}\text { Persentas } \\
\text { e } \\
(\%)\end{array}$ \\
\hline 1 & $\begin{array}{l}\text { Tidak Ada } \\
\text { Dukungan } \\
\text { Suami }\end{array}$ & 4 & 14,3 \\
\hline 2 & $\begin{array}{l}\text { Ada Dukungan } \\
\text { Suami }\end{array}$ & 24 & 85,7 \\
\hline & Total & 28 & 100,0 \\
\hline
\end{tabular}

Berdasarkan tabel di atas, menunjukkan bahwa sebagian besar yaitu sebanyak 24 orang $(85,7 \%)$ ada dukungan suami, sementara 4 orang $(14,3 \%)$ tidak ada dukungan suami.
Tabel 6

Distribusi Frekuensi Tingkat

Kecemasan Pada Ibu Primigravida

Trimester III Di Poli BKIA R. S. A D Tk II Udayana

\begin{tabular}{clcc}
\hline No & Tingkat Kecemasan & Fekuensi & $\begin{array}{c}\text { Persentase } \\
(\%)\end{array}$ \\
\hline 1 & Tidak Ada & 5 & 17.9 \\
& Kecemasan & 13 & 46.4 \\
2 & Kemasan Sedang & 9 & 32.1 \\
3 & Kecemasan Ringan & 1 & 3.6 \\
4 & Kemesan Berat & 28 & 100.0 \\
\hline & Total & &
\end{tabular}

Berdasarkan tabel di atas, menunjukkan bahwa sebagian besar yaitu sebanyak 13 responden $(46,4 \%)$ adalah tingkat kecemasan sedang, kemudian tingkat kecemasan berat 1 orang (3,6\%), sedang kecemasan ringan 9 orang $(32,1 \%)$ dan yang tidak ada dukungan suami dan mengalami kecemasan ringan dalam menghadapi persalinan sebanyak 4 orang $(100 \%)$.

\section{b. Analisa Bivariant}

Berdasarkan kerangka konsep, analisa bivariant telah menguji hubungan satu persatu antara variable bebas dengan variable terikat. Variabel bebas adalah karakteristik ibu primigravida trimester III yang meliputi umur, pendidikan, pekerjaan, terhadap tingkat kecemasan dalam menghadapi persalinan. Uji bivariant ini menggunakan uji chi-square. dengan menggunakan $\alpha=5 \%$. Untuk melihat besarnya hubungan dan besarnya nilai $p$. 
Arianty Duany Sinaga \& Luh Putu Widiastini: Hubungan Dukungan Suami Terhadap Tingkat Kecemasan Ibu Primigravida Trimester III dalam Menghadapi Persalinan di Rumah Sakit Tk II Udayana Denpasar

Tabel 7

Hasil Analisis Hubungan Dukungan

Suami terhadap Tingkat Kecemasan Ibu primigravida dalam menghadapi persalinan di Rumah Sakit Tingkat II Udayana

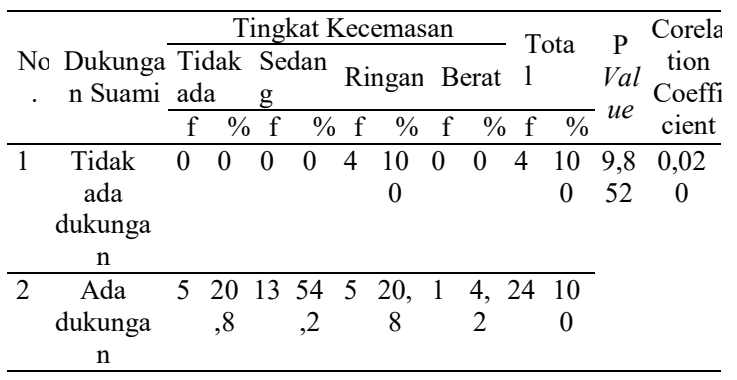

Berdasarkan tabel diatas menunjukkan bahwa hasil Uji person Chi- Square menunjukkan bahwa $p$ Value sebesar 9,852 dengan tingkat signifikan ( $a$ ) sebesar 0,020. Jadi dapat disimpulkan bahwa ada hubungan antara dukungan suami dengan tingkat kecemasan ibu primigravida. Terdapat hubungan dukungan suami dengan tingkat kecemasan ibu hamil primigravida dalam menghadapi persalinan. Berdasarkan hasil penelitian bahwa dukungan suami sangat penting bagi ibu yang sedang menghadapi persalinan

\section{PEMBAHASAN}

Berdasarkan hasil penelitian diatas menunjukkan tingkat kecemasan primigravida pada trimester III dalam menghadapi persalinan sebanyak 13 responden $(46,4 \%)$ dengan tingkat kecemasan sedang, berdasarkan alat ukur Hamilton Rating Scale For Anxiety nilai 21-27 adalah kecemasan sedang.

Tingkat kecemasan ringan yaitu 9 responden $(32,1 \%)$. Berdasarkan dari alat ukur nilainya 14-20 adalah kecemasan ringan, hal ini disebabkan karena ibu sudah mengetahui dan memahami tentang persalinan dan menganggap bahwa persalinan itu adalah hal yang normal yang dialami oleh seorang wanita.

Tingkat kecemasan berat yaitu 1 responden ( $3,6 \%)$, berdasarkan alat ukur nilainya 28-41 adalah kecemasan berat, kecemasan ini hampir sama dengan kecemasan sedang tetapi kecemasan berat ini lebih pada keadaan psikis dan tingkah laku ibu hamil, kecemasan berat terarah pada gejala perasaan cemas, ketegangan, ketakutan, gejala autonom dan tingkah laku. Tidak ada kecemasan sebanyak 5 responden $(02,8 \%)$, berdasarkan alat ukur nilainya $0-14$.

\section{KESIMPULAN}

Berdasarkan hasil penelitian dan pembahasan mengenai hubungan dukungan suami terhadap tingkat kecemasan ibu primigravida trimester III dalam menghadapi persalinan dapat disimpulkan ;

1. Dukungan suami pada ibu hamil dalam menghadapi persalinan sebagian besar mendapat dukungan jumlahnya 24 responden $(85,7 \%)$.

2. Tingkat kecemasan ibu hamil menghadapi persalinan sebagian besar dengan tingkat kecemasan sedang jumlahnya 13 responden $(46,4 \%)$.

3. Ada hubungan antara dukungan suami dengan tingkat kecemasan ibu primigravida trimester III dalam menghadapi persalinan dengan menunjukkan nilai $p$ Value sebesar $9,852(\alpha)=0,020$.

\section{DAFTAR PUSTAKA}

Ai Yeyeh R. (2014). Dokumentasi Kebidanan

Arif S. (2011). Metode Penelitian Kesehatan, Edisi Pertama. Jakarta ; Kencana 2011

Depkes RI. (2011). Profil Kesehatan Indonesia 2010. Jakarta ; 
Arianty Duany Sinaga \& Luh Putu Widiastini: Hubungan Dukungan Suami Terhadap Tingkat Kecemasan Ibu Primigravida Trimester III dalam Menghadapi Persalinan di Rumah Sakit Tk II Udayana Denpasar

Kementrian Kesehatan Republik Indonesia.

Janiwarty, H. (2013). Pendidikan Psikologi untuk Bidan : Suatu Teori dan Terapannya / Betshaida

Juliansyah, N. (2011). Metodologi Penelitian : Skripsi, Tesis, Disertasi, dan karya Ilmiah. Jakarta Kencana

Maimunah. (2011). Kecemasan ibu menjelang persalinan pertama. Jumal :Fakultas.

Medicastore. (2013). Media informasi obat - penyakit.

Notoatmodjo. S. (2010). Metodologi Penelitian Kesehatan, Jakarta, PT. Rineka Cipta.

Nurdinsyah, N. (2011). Buku Pintar Ibu dan Bayi, Jakarta EGC

Widiastini. (2016). "Pengaruh Massage Endorphin Terhadap Kecemasan Ibu Hamil Dalam Menghadapi Proses Persalinan Di Puskesmas Denpasar Utara III." Jurnal Dunia Kesehatan, vol. 5, no. 2, 2016

Widiastini. (2018). Buku Ajar Asuhan Kebidanan Pada Ibu Bersalin dan Bayi Baru Lahir. Bogor. In Med 
Arianty Duany Sinaga \& Luh Putu Widiastini: Hubungan Dukungan Suami Terhadap Tingkat Kecemasan Ibu Primigravida Trimester III dalam Menghadapi Persalinan di Rumah Sakit Tk II Udayana Denpasar 